\title{
Effect of Drying Methods on Chemical Composition, Mineral and Antioxidants of Saidy Date (Phoenix dactylifera L.) Fruits Residue. Ramadan, B. R. ${ }^{1}$; T. M. A. Mostafa ${ }^{2}$ and Walaa A. M. Ied $^{2}$ \\ ${ }^{1}$ Food Sci. and Tech. Dept., Faculty of Agric., Assiut Univ. \\ ${ }^{2}$ Food Tech. Research Institute, Agric. Research Center.
}

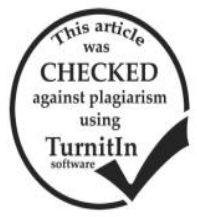

\section{ABSTRACT}

Low quality fruits of Saidy date (Semi-dry variety, high quality) were analyzed for their chemical composition, total phenolic and antioxidants content. The Saidy date fruits residue (DFR) obtained after juice separation was used in this study. The effect of drying methods (Hot air oven and microwave drying) on chemical composition, minerals, phenolics content and antioxidant activity of Saidy date fruits residue (DFR) was studied. Total carbohydrates was the major component of the DFR recorded 78.31, 75.88 and $75.53 \%$ of the fresh, hot air oven and microwave dried (DFR) samples; respectively. The DFR had high contents of total dietary fibers $(62.97,65.57$ and $64.90 \%$; respectively of the same samples, dwb). The insoluble dietary fibers had the highest values of the total dietary fibers recorded $48.86,49.38$ and $47.93 \%$; respectively of the same samples. While, the soluble dietary fibers varied from 14.11 to $16.97 \%$. The microwave dried (DFR) sample had the highest values of moisture, ash, crude protein, fat and fibers $(4.40,2.57,3.87,1.11$ and $16.92 \% \mathrm{dwb}$; respectively) compared to the hot oven air dried samples. The total phenolics content was 1.92, 2.12 and $2.28 \%$ of the fresh, hot air oven and microwave dried (DFR) samples; respectively. Besides, the antioxidant activity (DPPH) was 55.13, 62.62 and 60.13 of the same samples; respectively. Potassium content was the predominate value followed by phosphorous, magnesium and calcium in the dried DFR samples. With regard to the effect of drying methods on the composition of DFR samples, there are no differences among them except the drying time. Dates fruit residue (DFR) it may be a good source of dietary fibers, total phenolic contents and natural antioxidants which will ultimately result in adding value to the date fruits residue of low quality dates.

Keywords: Date fruit residue, Saidy, Microwave drying, Chemical composition, Total phenolics, Dietary fiber, Antioxidant activity.

\section{INTRODUCTION}

Date fruits (Phoenix dactylifera L.), a healthy and highly nutritious food, is one of the most widely distributed fruits in the world and also has played important role in people's daily lives for thousands of years (Al-Shahib and Marshall, 2003). World production of dates has increased significantly and clearly over the last 30 years. Arab countries produce about $74.5 \%$ of world history production. Egypt is the first country of the world's top ten producers of history (FAO, 2015).

Dates fruits are marketed around the world as highvalue confectionery. On the other hand, too date as a fresh fruit it was remains an important subsistence crop in most of the Arabian countries. Today, the production, application and manufacture of dates in the world had been continuously increasing in Arab countries and Egypt (Assous et al., 2009 and Chandrasekaran and Bahkali, 2013).

The dietary fiber of cereals is considerably used than those of fruits; while, fruit fibers are of better quality due to high total and soluble fibers content, as well as water and oil holding capacity and colonic ferment ability, In addition to lower content of phytic acid and caloric value. Thus, it was becomes necessary and important to develop different processes for the preparation of fruit fibers that decrease the losses of the associated bioactive compounds which may have exert higher health-promoting effects than dietary fiber itself. The dietary fibers concentrates can be used in different applications in the food industry while also obtaining excellent results. Fiber containing about $15 \%$ soluble dietary fibers (SDF) is fitted for to bind and retain water weight more than once (Herbafood, 2002). Dates are good source of dietary fiber (Elleuch et al., 2008). The percentage of dietary fiber was content of dates ranged from 4.4 to $11.4 \%$ this ratio relying on date variety and ripening stage (Spiller, 1993 and AlShahib and Marshall, 2002).
The Americans Dietary Guidelines published which was jointly published by the U.S. Department of Agriculture and by the Health and Human Services recommend eating foods containing enough amounts of fiber. On the other hand, the National Cancer Institute was recommends 20 to 30 grams of fiber in the day with a maximum of $(35 \mathrm{~g})$. Therefore, to meet these different requirements, fibers are supplement to different food products. In addition to health benefits, fiber is added to increased cooking productivity and water retention capacity, reduce fat retention, improve structural properties and structure, or also add as a multiplication factor to reduce the content of different calories (Larrauri, 1999).

A large part of the dates in countries producing dates (e.g. $30 \%$ loss of total produce) due to many reasons its inferior quality, damage, and smaller fruits for the unattractive appearance to the consumer (Besbes et al., 2009). Besides, it was also recorded that dates are also lost during various processes such as the sorting, conditioning and storage (Cheikh-Rouhou et al., 2006). Non-use of lower quality dates by-product for humans food is a real economic loss because it is rich in biologically active compounds that can be extracted and can be used as valueadded materials to food (Elleuch et al., 2008).

The date low quality is processed to produce many products such as date syrup. Consequently, are available very large amounts of date fruit residues (DFR), which is the by-product from syrup extraction (Hashim and Khalil, 2015).

The drying method is widely way used in processing various foods which allowing the extension the shelf life of the materials (Fernandes et al., 2010). Nevertheless, the processing may be cause many irreversible modifications to the polysaccharides in the cell wall, Which can affect its original structure. This may therefore promote significant modifications of these polymers in proposed physiological and pharmacological properties (Femenia, 2007). 
The aim of this study is to evaluate the effect of some drying methods on chemical composition, dietary fibre, phenolics content and antioxidant capacity of date fruit residue (DFR). Thence, the information will be useful to encourage DFR as a potential source of fibre in the development of functional food products with beneficial health benefits for humans.

\section{MATERIALS AND METHODS}

\section{Materials:}

Saidy dates fruit it was obtained from the Date Paking Factory, El-Kharga oasis, The New Valley governorate, Egypt, during the 2014 season. Date fruits were cutting into small pieces, weighed and then put in hot water $\left(75^{\circ} \mathrm{C}\right)$ at a ratio of $1: 3 \mathrm{w} / \mathrm{v}$ for $30 \mathrm{~min}$ with continuous stirring, The mixture obtained is filtered using a thin cloth according to Ramadan (1998 and 2000) to separation the juice from the date pulp (date fruit residue, DFR).

The date pulp residue (date cake) was divided into three parts; two of them were dried as the following ways: The first part of Saidy fruits residue (DFR) was dried by a microwave oven at $40 \mathrm{~W}$ for $14 \mathrm{~min}$. The second DFR was dried by hot-air oven at $60^{\circ} \mathrm{C}$ for 5 hours (Ied, 2011). The dried DFR samples were ground by pattern laboratory mill and sieved (0.125 mesh). All DFR samples were packed in laminate sacs PPA packing material (polyethylene, polyester and aluminium foils). Finally, cakes powders were preserved until analyses at $5 \pm 2{ }^{\circ} \mathrm{C}$.

\section{Analytical Method:}

\section{Chemical and physical analysis:}

The moisture content was determined by drying the samples at $70^{\circ} \mathrm{C}$. Sugars (reducing and total), crude fiber, protein, fat, ash content and the acidity as malic acid by titration were appointed according to AOAC (2005) methods. Non-reducing sugars calculated by difference. The mineral content of DFR was estimated, Sodium, potassium and calcium were determined in samples using the Flame Photometer (Gallenkamp, FGA 330, England). Iron, copper, manganese, magnesium and also were determined the zinc using Perkin Elmer Atomic Absorption Spectrophotometer (model 80, England).

Contents of soluble, insoluble and total dietary fiber were determined in the different samples of date fruit residues (DFR) powder as according to Asp et al. (1983).

Total phenolics compounds it was determined also, using Folin- ciocalteu reagent as described by Velioglu et al. (1998) as pyrogallol. Antioxidant capacity; the free radical scavenging activity of extract date fruits was determined using the 1, 1- diphenyl-2-picrylhydrazyl (DPPH) method according to (Ao et al., 2008).

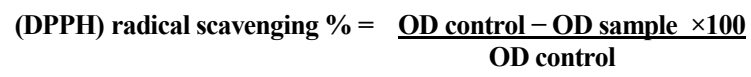

\section{RESULTS AND DISCUSSION}

\section{Chemical composition of Saidy date fruits:}

Consumer interest focused mainly on the nutritional characteristics of the product. Therefore, the development of a quality profile of history will include an assessment of the overall chemical composition, total polyphenol content and the antioxidant activity of Saidy date fruits at Tamr stage were determined and results showed in (Table 1). The moisture content of Saidy fruits was $14.28 \%$. This result is in agreement with those obtained by $\mathrm{Al}$ Abdulhadi et al.(2011) varied from 13.96 to $15.52 \%$ of three date varieties, while, it is a lower than that reported by Ismail (2011).

The data showed that the total sugars content was $77.12 \%$ while, the reducing and non- reducing sugars were 71.21 and $5.91 \%$; respectively of Saidy dates. These results are in agreement with those reported by Abd-Elkarim (2016). Abd El-Majeed (2016) found that the total sugar, reducing and non- reducing sugars content of Saidy date were $77.93,74.10$ and $3.83 \%$; respectively. The data showed that the crude fiber content was $2.89 \%$ which is in the same line with that reported by Abd El-Majeed (2016). However, it is lower than that reported by Abd-Elkarim (2016) in Saidy fruits $(9.26 \%)$.

The ash content $(2.47 \%)$ of Saidy fruits in the line with those reported by Abd-Elwahid (2007). The crude protein content was $2.38 \%$, which in the same trend of those obtained by Abd Ellah (2009). The data (Table 1) also showed the fat content $(1.20 \%)$ of Saidy fruits agreement with those obtained by Ramadan (1990 and 1995) and Abd-Elkarim (2016). Abd El-Majeed (2016) found that the fat content $1.49 \%$ of Saidy dates.

The total polyphenol content of Saidy date fruits was $2.60 \%$ which are higher than that reported by Ismail (2011) on Siwi date (1.16 \%) at Tamr stage. Assous (1999) reported that the content of total polyphenol (expressed as pyrogallol) at Tamr stage of Siwi date was $0.78 \%$ (dwb). Abd El-Majeed (2016) recorded that the Saidy date flesh contained $297.37 \mathrm{mg}$ as gallic acid/ $100 \mathrm{~g}$ on dry weight basis. This difference in total polyphenols from date fruits can be due to the different criteria used, the date of dates and the maturity of the dates fruits studied.

The data showed that the antioxidant activity of Saidy date fruits was $70.48 \%$. This result is in the same line with those obtained by Abd El- galil (2017), found the antioxidant activity of El Sakkoti and Tamr El wadi was 79.61and $76.15 \%$; respectively.

Table 1. Chemical composition of Saidy date fruits* (\% dry weight basis; dwb, except moisture):

\begin{tabular}{lc}
\hline Components & \% \\
\hline Moisture & $14.28 \pm 0.15$ \\
Ash & $2.47 \pm 0.015$ \\
Crude protein & $2.38 \pm 0.025$ \\
Crude fat & $1.20 \pm 0.02$ \\
Crude fiber & $2.89 \pm 0.03$ \\
Nitrogen free extract & $93.95 \pm 0.5$ \\
Reducing sugar & $71.21 \pm 0.08$ \\
Non reducing sugar & $5.91 \pm 0.014$ \\
Total sugars & $77.12 \pm 0.09$ \\
Total phenolic content & $2.60 \pm 0.02$ \\
Antioxidant activity(DPPH) & $70.48 \pm 0.2$ \\
\hline
\end{tabular}

*Means of three replicates \pm SD

\section{Chemical composition of date fruit residue (DFR):}

The results (Table 2) indicated that the moisture content of Saidy date fruit residue (DFR) was 20.22, 4.25 and $4.40 \%$ for the fresh, oven hot air and microwave dried samples; respectively. The moisture content of fresh DFR was higher than that recorded by Al-Farsi et al. (2007) and Hashim and Khalil (2015). Hasnaoui et al. (2012) reported 
that date fiber concentrates from Moroccan date flesh exhibited moisture content ranged from 4.43-12.29\%. Hamoda (2018) reported that moisture content of Saidy date fiber was $11.53 \%$. The differences compositional can be related to the date varieties and the different types of techniques used in extraction.

Carbohydrate was the major component of Saidy DFR date, recorded 78.31, 75.88 and $75.53 \%$ (dry weight basis) for the fresh, oven hot air and microwave dried DFR samples; respectively. Relatively similar carbohydrate values were reported for the Tunisian date fiber concentrates (Elleuch et al., 2008). Hamoda (2018) found that the carbohydrate values content $84.56 \%$ of Saidy date fiber.

Moreover, ash and crude protein content of the studied samples varied from 1.91 to $2.57 \%$ and 2.87 to $3.87 \%$; respectively. Data in (Table 2) are in agreement with that recorded by Elleuch et al. (2008), Hashim and Khalil (2015) and Hamoda (2018).

Data in Table 2 illustrated the crude fat and fiber ranged from 1.11 to $1.25 \%$ and 15.66 to $16.92 \%$; respectively. The DFR reducing, non-reducing and total sugars were 12.71, 1.19 and 13.90; 11.92, 1.00 and 12.92; and $12.04,1.11$ and $13.15 \%$ for the fresh, oven hot air and microwave dried DFR; respectively. These data is consistent with that reported by Al-Farsi et al. (2005 and 2007), Figuerola et al. (2005), Elleuch et al. (2008), Besbes et al. (2009), Borchani et al. (2012), Hashim and Khalil (2015) and Hamoda (2018) .

The contents of soluble (SDF), insoluble (ISDF) and total dietary fiber (TDF) Table (2) of the Saidy DFR varied from 14.11 to $16.97 \%, 47.93$ to $48.86 \%$ and 62.97 to $65.57 \%$ of the fresh, oven hot air and microwave dried DFR; respectively. These values are agreement with those recorded by Figuerola et al. (2005). Besides, Elleuch et al. (2008) founded that the TDF content for freeze-dried dietary fiber concentrates ranged from 88 to $92 \%$ for Deglet Nour and Alligh; respectively. The reason for the difference can be attributed to growth, climatic conditions, geographic origin, or an important factor, the difference in different extraction methods.

By-products of dates can be considered a good source of DF. Contents of soluble DF in dates are relatively high compared to cereals and cereal derivatives which have a low soluble DF $(0.4-4 \%)$ (Abdul-Hamid and Luan, 2000 and Prosky et al., 1988). Results are in the same line with that recorded by Al-Farsi et al. (2007), Borchani et al (2011) and Hashim and Khalil (2015), but lower than that recorded by Elleuch et al. (2008).

Hamoda (2018) reported that date fiber concentrates (DF) from Saidy date was 64.29, 20.76 and 43.53 soluble, insoluble and total dietary fibers; respectively.

Thus, we can explain this by the presence of a part of the protein that is strongly linked to the components of the cell wall (O’Neill and Selvendran, 1985 and Redgwell and Selvendran, 1986) as well as another part of the protein that is insoluble in water.

The total phenolics content was 1.92, 2.12 and $2.28 \%$ of the fresh, oven hot air and microwave dried DFR; respectively. The results are in the same line with that recorded by Al-Farsi et al. (2005 and 2007). Cell wall heat treatment may disrupt and release phenolic compounds from the insoluble part of the plant (Choi et al., 2006 and Jeong et al., 2004). Compared to fresh fruits (Ancos et al., 2000 and Moyer et al., 2002) as well as dried fruits (Wu et al., 2004), dates and date by-products (on the particular seeds) can be considered as rich sources of total phenols.

Table 2. Effect of drying methods on the chemical composition of Saidy date fruits residue (DFR)* (\% dry weight basis except moisture): Date fruits residues (DFR)

\begin{tabular}{lccc} 
Composition & Fresh & Oven dried & $\begin{array}{c}\text { Microwave } \\
\text { dried }\end{array}$ \\
\hline Moisture & $20.22 \pm 0.09$ & $4.25 \pm 0.005$ & $4.40 \pm 0.002$ \\
Ash & $1.91 \pm 0.008$ & $2.40 \pm 0.03$ & $2.57 \pm 0.06$ \\
Crude protein & $2.87 \pm 0.04$ & $3.78 \pm 0.05$ & $3.87 \pm 0.04$ \\
Crude fat & $1.25 \pm 0.002$ & $1.08 \pm 0.01$ & $1.11 \pm 0.009$ \\
Crude fiber & $15.66 \pm 0.09$ & $16.86 \pm 0.009$ & $16.92 \pm 0.1$ \\
Total carbohydrate ** & $73.75 \pm 0.2$ & $88.49 \pm 0.2$ & $88.05 \pm 0.15$ \\
Reducing sugar & $12.71 \pm 0.15$ & $11.92 \pm 0.009$ & $12.04 \pm 0.15$ \\
Non reducing sugar & $1.19 \pm 0.009$ & $1.00 \pm 0.01$ & $1.11 \pm 0.02$ \\
Total sugars & $13.90 \pm 0.15$ & $12.92 \pm 0.15$ & $13.15 \pm 0.15$ \\
Total dietary fiber (TDF) & $62.97 \pm 0.2$ & $65.57 \pm 0.2$ & $64.90 \pm 0.2$ \\
Soluble dietary fiber(SDF) & $14.11 \pm 0.2$ & $16.19 \pm 0.10$ & $16.97 \pm 0.15$ \\
Insoluble dietary fiber (ISDF) & $48.86 \pm 0.08$ & $49.38 \pm 0.02$ & $47.93 \pm 0.15$ \\
Total phenolic content & $1.92 \pm 0.008$ & $2.12 \pm 0.05$ & $2.28 \pm 0.03$ \\
Antioxidant activity(DPPH) & $55.13 \pm 0.09$ & $62.62 \pm 0.2$ & $60.13 \pm 0.1$ \\
\hline
\end{tabular}

* Means of triplicates ** Carbohydrate was calculated by difference

The antioxidant activity (DPPH) was 55.13, 62.62 and $60.13 \%$ of the fresh, oven hot air and microwave dried DFR samples; respectively. These results are in the same line with that recorded by Al-Farsi et al. (2007) and Borchani et al. (2011). High antioxidant activity has been reported from dates by Vayalil (2002) and Guo et al. (2003). These values of antioxidant activity have also been reported much higher than those found in mango fruit fibers $(16.14 \mathrm{mg} / \mathrm{g})$, also guava fiber $(26.3-58.7 \mathrm{mg} / \mathrm{g}$ ) (Jiménez-Escrig et al., 2001, Ubando-Rivera et al., 2005, and Vergara-Valencia et al., 2007). On another side, though the researchers was used extraction solvents and different methods, which make any quantitative difficult, Vayalil (2002) was reported that antmutagenic activities and potent antioxidant of dates implicate free radical scavenging activity.

\section{Minerals content of the (DFR) powder:}

The minerals content of Saidy date fruits residues powder (DFR) is shown in Table 3. Potassium was the major (501.36 and $503.60 \mathrm{mg}$ ) followed by phosphorous (468.24 and $470.69 \mathrm{mg}$ ), magnesium (370.51 and 368.04 $\mathrm{mg})$, calcium (118.45 and $118.11 \mathrm{mg}$ ) and sodium (45.51, $43.12 \mathrm{mg}$ ) $/ 100 \mathrm{~g}$ of the oven hot air and microwave dried samples; respectively.

The dried DFR samples contained a low level but a good source of iron, manganese, zinc and copper (Table 3). These results are in close agreement with those of many other studies (Borchani et al., 2010 and Hashim and Khalil, 2015). While, these data in Table 3 Where there is a significant difference from the values reported for date fruits flesh (Elleuch et al., 2008). Hamoda (2018) reported that mineral content of DF was potassium concentration was the highest $(754 \mathrm{mg})$ followed with in descending order by phosphorus $(501 \mathrm{mg})$, magnesium $(452 \mathrm{mg})$, and 
calcium $(154 \mathrm{mg}) / 100 \mathrm{~g}$ dry matter of DF. The variation of mineral content could can arise due to several reasons including originate from the same cultivar, agro-climatic and different environmental conditions (Yousif et al., 1982).

The high amount of potassium coupled with low amount of sodium serves acts as a systematic strategy to prevent or control high blood pressure, decrease cardiovascular morbidity and mortality, kidney disease, stroke, and cardiovascular disease (Aaron and Sanders, 2013).

Table 3. Effects of the drying methods on the minerals contents $(\mathrm{mg} / \mathbf{1 0 0 g} \mathrm{dwb})$ of Saidy date fruits residue (DFR):

\begin{tabular}{lcc}
\hline Element & \multicolumn{2}{c}{ Date fruits residues (DFR) } \\
Oven dried & $\begin{array}{c}\text { Microwave } \\
\text { dried }\end{array}$ \\
\hline Sodium (Na) & 45.51 & 43.12 \\
Potassium (K) & 501.36 & 503.60 \\
Calcium (Ca) & 118.45 & 118.11 \\
Phosphorous (P) & 468.24 & 470.69 \\
Magnesium (Mg) & 370.15 & 368.04 \\
Zinc (Zn) & 10.119 & 10.133 \\
Iron (Fe) & 14.00 & 14.31 \\
Copper $(\mathrm{Cu})$ & 5.129 & 5.132 \\
Manganese $(\mathrm{Mn})$ & 0.210 & 0.223 \\
\hline
\end{tabular}

\section{CONCLUSIONS}

The results indicated that the date fruit residues (DFR), appears as a good and suitable source for dietary fiber, total phenolics and antioxidant capacity. Therefore, could be considered the DFR as substitution dietary fiber with health benefits and source for different food products. Therefore, this will provide a solution for disposal processing by-products of dates and benefits to the date industry.

\section{REFERENCES}

Aaron, K.J. and Sanders, P.W. (2013). Role of dietary salt and potassium intake in cardiovascular health and disease: a review of the evidence. In: Mayo Clinic Proceedings, Vol. 88, No. 9. Elsevier, pp. 987-995.

Abd El-galil, Zeinab. A. H. (2017). Studies on the use of dried date powder on some food products. Ph.D. Thesis, Food Sci. Dept., Faculty of Agric., Minia Univ., Egypt.

Abd-Elkarim, Naglaa. A. (2016). Chemical, nutritional and technological studies on date products. Ph.D. Thesis, Food Sci. and Nutrition Dept., Faculty of Agric., Sohag Univ., Egypt.

Abd-Ellah, A. E. I. (2009). Chemical and technological studies on some Sudanese date cultivars. Ph.D. Thesis, College of Graduate Studies, Nile Valley Univ., Sudan.

Abd El-Majeed, M. H. (2016). Effect of some technological and storage processes on chemical composition and quality properties of certain date varieties. M.Sc. Thesis, Food Sci. and Tech. Dept., Faculty of Agric., Assiut Univ., Egypt.
Abd-Elwahid, A. A. (2007). Quality evaluation of some local date palm fruits under Rubatab area. M.Sc. Thesis, Fac. of Agric., Nile Valley Univ., Atbara, Sudan.

Abdul-Hamid, A. and Luan, Y. S. (2000). Functional properties of dietary fiber prepared from defatted rice bran. Food Chem., 68, 15-19.

Al-Abdoulhadi, I.A.; Al-Ali, S.; Khurshid, K.; Al-Shryda, F.; Al-Jabr, A.M. and Ben Abdallah, A. (2011). Assessing fruit characteristics to standardize quality norms in date cultivars of Saudi Arabia. Indian J. of Sci. and Tech., 4: 1262-1266.

Al-Farsi, M.; Alasalvar, C.; Morris, A.; Barron, M. and Shahidi, F. (2005). Comparison of anti-oxidant activity, anthocyanins, carotenoids, and phenolics of three native fresh and sun-dried dates (Phoenix dactylifera L.). J. Agric. Food Chem., 53: 75927599.

Al-Farsi, M.; Alasalvar, C.; Al-Abid, M.; Al-Shoaily, K.; Al-Amry, M. and Al-Rawahy, F. (2007). Compositional and functional characteristics of dates, syrups and their by-products. Food Chem., 104 (3): 943-947.

Al-Shahib, W. and Marshall, R. J. (2002). Dietary fiber content of dates from 13 varieties of date palm (Phoenix dactylifera L.). Inter. J. Food Sci. and Tech., 37: 719-721.

Al-Shahib, W. and Marshall, R. J. (2003). Fatty acid content of the seeds from 14 varieties of date palm (Phoenix dactylifera L.) Int. J. Food Sci. Tech. 38:709-712.

Ancos, B.; Gonzalez, E. M. and Cano, M. P. (2000). Ellagic acid, vitamin $\mathrm{C}$ and total phenolic contents and radical scavenging capacity affected by freezing and frozen storage in raspberry fruit. J. of Agric. and Food Chem., 48, 4565-4570.

AOAC (2005). Association of Official Analytical Chemists, Official method of Analysis, fifteenth ed. Published, Arligton, Virginas, USA .

Ao, C.; Li, A.; Elzaawely, A.A.; Xuan, T.D. and Tawata, S. (2008). Evaluation of antioxidant and antibacterial activities of Ficus microcarpa L. fil. extract. Food Control, 19, 940-948.

Asp, N. G.; Johansson C. G.; Hallmer, H. and Siljeström, M. (1983). Rapid enzymatic assay of insoluble and soluble dietary fiber. J. Agric. Food Chem. 31: 476 $-482$.

Assous, M. T. M. (1999).Production and evaluation of Siwi date syrup (Dibis)". M.Sc. Thesis, Food Tech. Dept., Fac. of Agric., Cairo Univ., Egypt.

Assous, M. T. M.; Neamah. R. A. and Eman F.M. (2009). Production and evaluation of date-skim milk powder. Bulletin of Faculty of Agriculture, Cairo University, vol.: 296-305.

Besbes, S.; Drira, L.; Blecker, C.; Deroanne, C. and Attia, H. (2009). Adding value to hard date (Phoenix dactylifera L.): Compositional, functional and sensory characteristics of date jam. Food Chem., 112: 406-411. 
Borchani, chema.; Besbes, S.; Blecker, C.; Masmoudi, Manel.; Bact, R. and Attia, H.(2010). Chemical properties of 11 date cultivars and their corresponding fiber extracts. African. J. of Biotechenology, 9 (26): 4096-4105.

Borchani, C.; Besbes, S.; Masmoudi, M.; Blecker, C. and Paquot, M. (2011). Effect of drying methods on physico-chemical and antioxidant properties of date fibre concentrates. Food Chem., 125: 1194-1201.

Borchani, C.; Besbes, S.; Masmoudi, M.; Blecker, C.; Bouaziz, M. A and Attia, H. (2012). Influence of oven-drying temperature on physicochemical and functional properties of date fiber concentrates. Food Bioprocess Tech., 5:1541-1551.

Chandrasekaran, M. and Bahkali, A. H. (2013). Valorization of date palm (Phoenix dactylifera $\mathrm{L}$ ) fruit processing by-products and wastes using bioprocess technology. A review Saudi J. of Biological Sci., 20: 105-120.

Cheikh-Rouhou, S.; Baklouti, S.; Hadj-Taieb, N.; Besbes, S.; Chaabouni, S. and Blecker, C. (2006). Elaboration d'une boisson à partir d'écart de triage de dattes: Clarification par traitement enzymatique et microfiltration. Fruit, 61, 389-399.

Choi, Y., S.M. Lee, J. Chun, H.B. Lee and J. Lee (2006). Influence of heat treatment on the antioxidant activities and polyphenolic compounds of shitake (Lentinus edodes) mushroom. Food Chem. 99: 381387.

Elleuch, M.; Besbes, S.,; Roiseux, O.; Blecker, C.; Deroanne, C.; Deroanne, C.; Drira, N. and Attia, H. (2008): Chemical composition and characteristics of the dietary fiber. Food Chem., 111: 676-682.

FAO (2015). Statistical databases. http://faostat.fao.org.

Femenia, A. (2007). High-value co-products from plants: cosmetics and pharmaceuticals. In K. W. Waldron (Ed.), Waste management and co-product recovery in food processing. Cambridge: Woodhead Publishing Limited.

Fernandes, F.A. N.; Rodrigues, S.; Law, C. L. and Mujumdar,A. S. (2010). Drying of exotic tropical fruits: a comprehensive review. Food and Bioprocess Technology, doi:10.1007/s11947-0100323-7.

Figuerola, F.; Hurtado, M. L.; Estévez, A. M.; Chiffelle, I. and Asenjo, F. (2005). Fibre concentrates from apple pomace and citrus peel as potential fiber sources for food enrichment. Food Chem., 91: 395401.

Guo, C.; Yang, J.; Wei, J.; Li, Y.; Xu, J. and Jiang, Y. (2003). Antioxidant activities of peel, pulp and seed fractions of common fruits as determined by FRAP assay. Nutrition Research, 23, 1719-1726.

Hamoda, A. M. M. (2018). Production of functional food products using date fibers. Ph.D. Thesis, Food Sci. and Tech. Dept., Faculty of Agric, Menoufia Univ., Egypt.

Hashim, I. B. and Khalil, A. H. (2015). Composition and functional properties of the date fruit residue a byproduct of date syrup/Debis production. Nutr. Food Tech., 1 (2): doi http://dx.doi.org/10.16966/24706086.108 .
Hasnaoui, A.; Elhoumaizi, M. A.; Borchani, C.; Attia, H. and Besbes, S. (2012). Physicochemical characterization and associated antioxidant capacity of fiber concentrates from Moroccan date flesh. Int. J. Latest Trends Agric. Food Sci. 2:94-102.

Herbafood (2002). Herbacel AQ plus apple and citrus fiber. Available from WWW. herbafood.de / eaqplus.pdf.Date November 2002.

Ied, walaa. A. M. (2011). Physical, chemical and technological studies on some vegetables dried by different methods. M.Sc . Thesis, Food Sci. Dept., Fac. of Agric., Minia Univ., Egypt.

Ismail, O. H. (2011). Influence of some technological treatments on the quality of Siwi date fruits and syrup. M.Sc. Thesis, Food Tech. Dept., Fac. of Agric., Fayoum Univ., Egypt.

Jeong, S. M.; Kim, S.Y.; Kim. D.R.; Jo, S.C.; Nam, K. C.; Ahn, D.U. and Lee, S.C. (2004). Effect of heat treatment on the antioxidant activity of extracts from citrus peels. J. Agri. Food Chem., 52: 33893393.

Jiménez-Escrig, A.; Rincón, M.; Pulido, R. and SauraCalixto, F. (2001). Guava Fruit (Psidium guajava L.) as a new source of antioxidant dietary fiber. J. of Agric. and Food Chem., 49: 5489-5493.

Larrauri, J. A. (1999). New approaches in the preparation of high dietary fiber powders from fruits byproducts. Trend in Food Sci. and Tech., 10: $3-8$. (C.F. Figuerola, 2005).

Moyer, R. A.; Hummer, K. E.; Finn, C. E.; Frei, B. and Wrolstad, R. E. (2002). Anthocyanins, phenolics, and antioxidant capacity in diverse small fruits: Vaccinium, Rubus, and Ribes. J. of Agric. and Food Chem., 50: 519-525.

O'Neill, M. A., and Selvendran, R. R. (1985). Hemicellulosic complexes from the cell walls of runner beans (Phaseolus coccineus). Biochem. J., 227: 475-481.

Prosky, L.; Asp, N. G.; Schweizer, T. F.; De Vries, J. W. and Furda, I. (1988). Determination of insoluble, soluble, and total dietary fibre in food products: Interlaboratory study. J. of Association Official Analytical Chem., 71: 1017-1023.

Ramadan, B. R. (1990). Chemical and technological studies on some New Valley dates. M. Sc. Thesis, Food Sci. and Tech. Dept., Fac. of Agric., Assiut., Egypt.

Ramadan, B. R. (1995). Biochemical, nutritional and technological studies on dates. Ph.D. Thesis, Food Sci. and Tech. Dept., Fac., of Agric., Assiut Univ., Egypt.

Ramadan, B. R. (1998). Preparation and evaluation of Egyptian date syrup. Proc. of. The $1^{\text {st }}$ Inter. Conf. on date palm, United Arab Emirates Univ.,Al-Ain:8699.

Ramadan, B.R. (2000). Storage stability and utilization of date surup(Dibs). $1^{\text {st }}$ mansoura. Conf. of Food Sci. and Dairy Tech., 13-28.

Redgwell, R., and Selvendran, R. R. (1986). Structural features of cell-wall polysaccharides of onion (Allium cepa). Carbohydrate Research, 157: 183199. 
Spiller GA (1993) Handbook of Dietary Fiber in Human Nutrition $2^{\text {nd }}$ Ed. Boca Raton, Florida: CRC. (pp 588)

Ubando-Rivera, J., Navarro-Ocaña, A. and ValdiviaLópez, M. A. (2005). Mexican lime peel: Comparative study on contents of dietary fibre and associated antioxidant activity. Food Chem., 89: 57-61.

Vayalil, P. K. (2002). Antioxidant and antimutagenic properties of aqueous extract of date fruit (Phoenix dactylifera L.). J. of Agric. and Food Chem., 50: $610-617$.

Velioglu, Y.S.; Mazza, G.; Gao, L. and Oomah, B. D. (1998). Antioxidant activity and total phenolics in selected fruits, vegetables, and grain products. J. Agric. Food Chem.,46: 4113-4117.
Vergara-Valencia, N.; Granados-Pérez, E.; AgamaAcevedo, E.; Tovar, J.; Ruales, J. and Bello-Pérez, L. A. (2007). Fiber concentrate from mango fruit: characterization, associated antioxidant capacity and application as a bakery product ingredient. LWTFood Sci. and Tech., 40: 722-729.

Wu, X.; Beecher, G.; Holden, J.; Haytowitz, D.; Gebhardt, S. and Prior, R. (2004). Lipophilic and hydrophilic antioxidant capacities of common foods in the United States. J. of Agric. and Food Chem., 52: 4026 - 4037.

Yousif, A.K.; Benjamin, N.D.; Kado, A.; Alddin, S.M. and Ali, S.M. (1982). Chemical composition of four Iraqi date cultivars. Date Palm J., 1, 285-294.

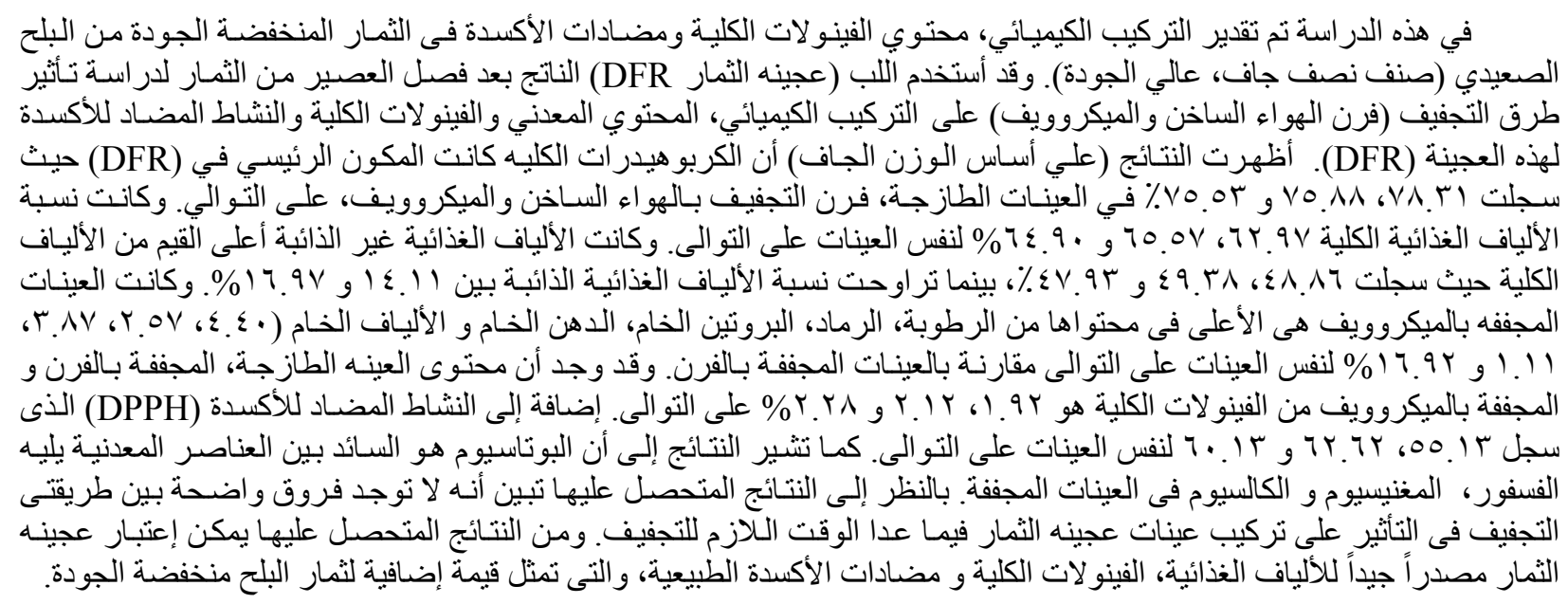

